\title{
Penggunaan Dual Sensor Leap Motion Controller untuk Sistem Isyarat Bahasa Indonesia
}

\author{
Syaiful Nugraha*, Darlis Heru Murti**, Wijayanti Nurul Khotimah*** \\ * Departemen Informatika, Univeristas Musamus Merauke \\ ** Departemen Informatika Institut Teknologi Sepuluh Nopember Surabaya \\ *** Departemen Informatika Institut Teknologi Sepuluh Nopember Surabaya \\ *syanugraha29@gmail.com, ** darlis.herumurti@gmail.com, *** wijaycs@gmail.com
}

\begin{abstract}
Bahasa isyarat adalah bahasa yang dibentuk dengan kombinasi gerakan jari, tangan, tubuh serta ekspresi wajah yang digunakan oleh para penyandang disabilitas seperti tunarungu dan tunawicara. Salah satu pengenalan bahasa isyarat tersebut adalah pengenalan dengan menggunakan teknologi sensor Leap Motion Controller (LMC). Akan tetapi pada penerapannya, sensor $L M C$ tidak selalu dapat mengenali semua jari dengan baik. Hal ini dikarenakan pembentukan dari bahasa isyarat yang saling bersentuhan antar jari, jari yang dilipat, tersembunyi ataupun terhalang oleh jari lainnya. Sehingga pada penelitian ini diusulkan penggunaan dual sensor LMC berbasis berbasis Logarithmic Learning for Generalized Classifier Neural Network (L-GCNN) yang bertujuan untuk mencegah dan meminimalisir adanya kesalahan dalam mengenal bahasa isyarat dari jari yang dibentuk. $L-G C N N$ digunakan dan dimanfaatkan untuk dapat meningkatan akurasi pengenalaan isyart terhadap masingmasing sensor $L M C$. Tahapan proses yang dilakukan adalah mendesain tata letak sensor dan mengkombinasikan data fitur dari masing-masing sensor baik yang bersifat statis dan dinamis yang kemudian akan diklasifikasikan. Dari hasil pengujian yang dilakukan, penggunaan dual sensor $L M C$ ini dapat mengenal isyarat bahasa indonesia yang diberikan. Skema yang terbaik adalah dengan mengacu pada tata letak multi sensor yang saling berhadapan membentuk sudut 120 derajat dengan tingkat akurasi sebesar $86,42 \%$, dengan rata-rata akurasi dari keseluruhan skenario sebesar 84,36\%. Adanya desain tata letak sensor $L M C$ dan kombinasi penggabungan data fitur masing-masing sensor dapat meningkatkan akurasi pengenalan dengan rata-rata peningkatan mencapai $5,35 \%$.
\end{abstract}

Keyword: bahasa isyarat, Leap Motion Controller, dual sensor, kombinasi fitur, Logarithmic Learning for Generalized Classifier Neural Network

\section{Introduction}

Bahasa isyarat adalah bahasa yang dibentuk oleh kombinasi dari gerakan jari, orientasi gerakan tangan, lengan, tubuh serta gerak bibir dan ekspresi wajah. Komunikasi bahasa isyarat yang ada di Indonesia adalah salah satu komunikasi bahasa isyarat yang dibangun dengan mengadopsi dari bahasa isyarat American Sign Language $(A S L)$ yang dimiliki oleh negara Amerika. Komunikasi yang dilakukan antara penyandang disabilitas ini tentunya akan sangat sulit dipahami oleh orang normal pada umumnya serta akan kesulitan untuk mengetahui dan mengerti bahasa isyarat yang disampaikan oleh tuna rungu dan tuna wicara. Hal ini dikarenakan adanya perbedaan dalam metode dan cara komunikasi, begitu juga sebaliknya. Sehingga dibutuhkan sebuah sistem yang dapat menerjemahkan perbedaan metode komunikasi tersebut antara komunikasi bahasa isyarat dengan komunikasi bahasa normal.

Dalam bidang teknologi tentunya, selama dekade terakhir ini telah banyak penelitian dilakukan dan beberapa penelitian pengenalan bahasa isyarat tersebut adalah berfokus pada algoritma yang digunakan atau metode yang terdiri dari isyarat statis dan dinamis[1]. Telah banyak karya penelitian yang diarahkan dan dilakukan untuk mengembangkan pengenalan bahasa isyarat yang berbeda-beda. Beberapa penelitian tersebut adalah American Sign Language ( $A S L)$ [2], Malaysian Sign Language[3], Indian Sign Language (ISL) [4] dan Arabic Sign Language $(A r S L)$ [5]. Penelitian bahasa isyarat lainnya dengan melakukan pendekatan berbasis citra dan juga sensor, dimana algoritma bahasa isyarat dibagi menjadi tiga bagian yaitu pengenalan berdasarkan huruf, kata dan kalimat. Dimana teknik pengenalan kata adalah menangkap dan menganalisa setiap citra yang berkelanjutan yang merepresentasikan keseluruhan kata dalam bahasa isyarat[6]. 
Perkembangan penelitian bahasa isyarat saat ini tentunya tidak hanya bergantung pada algoritma dan teknik pengenalan isyarat saja, akan tetapi para peneliti juga telah banyak mempresentasikan dari teknologi sensor yang ada. Sensor seperti smart glove [7], kamera digital [8] hingga kamera kinect [9] digunakan sebagai alat masukan (input device) bagi manusia untuk berinteraksi dengan sistem dan mengenali bahasa isyarat yang diberikan. Teknologi sensor lainnya yang terkini adalah Leap Motion Controller (LMC). Pada penelitian mengenai bahasa isyarat dengan menggunakan $L M C$ yang telah diperkenalkan ini, contohnya adalah penelitian dengan menggunakan K-Nearest Neighbor (KNN) serta Support Machine Vector (SVM) digunakan sebagai algoritma yang mengaklasifikasi 26 huruf alfabet dari bahasa isyarat yang ada [10]. Kombinasi dari gabungan fitur statis untuk isyarat statis dan fitur dinamis untuk isyarat berupa gestur, diperoleh dari $L M C$ berdasarkan pada metode Logarithmic learning for generalized classifier neural network (L-GCNN) [11]. Akan tetapi pada penerapannya, dikatakan bahwa sensor penangkap gerak seperti kinect dan $L M C$ tidak selalu dapat mengenali semua jari. Karena tidak hanya jari yang saling bersentuhan, tetapi jari yang dilipat, tersembunyi ataupun terhalang jari lainnya dapat menyebabkan sensor kamera tidak dapat mengenali dan menangkap dengan baik[12]. Sehingga dibutuhkan beberapa sumber sensor lainnya atau lebih dari satu sensor (multi sensor) untuk dapat meminimalisir dan mengatasi hal tersebut.

Oleh karena itu, pada penelitian ini diusulkan sebuah metode pengenalan isyarat pada Sistem Isyarat Bahasa Indonesia (SIBI) yang mengkombinasikan informasi dan data berupa fitur statis dan fitur dinamis yang diperoleh dari dua buah sensor LMC (dual sensor). Metode yang diusulkan mencakup tahapan desain dual sensor, pengumpulan data, ekstraksi fitur serta tahapan klasifikasi. Sehingga pemanfaatan dari penggunaan dual sensor ini dapat memaksimalkan proses deteksi dan capture sensor terhadap isyarat tangan yang diberikan serta dapat meningkatkan akurasi pengenalan terhadap sistem isyarat bahasa Indonesia.

\section{Research Method}

Pada bagian ini, dijelaskan beberapa teori dasar pendukung penelitian, desain penelitian dan metode serta tahapan-tahapan penelitian yang dilakukan, seperti berikut :

\subsection{Leap Motion Controller (LMC)}

Sistem $L M C$ merupakan sistem yang dapat mengenal gerakan tangan, menggunakan sensor optik dan cahaya inframerah. Sensor yang diarahkan sepanjang arah sumbu y saat controller dalam pengoperasian standar dan memiliki bidang pandang 150 derajat. Jarak efektif $L M C$ memanjang diatas perangkat dari $25-600$ milimeter (1 inci - 2 kaki). $L M C$ dapat mendeteksi tangan, jari dan alat yang berada pada bidang pandang $L M C$. Setiap objek frame menunjukkan frame yang mengandung daftar data deteksi seperti tangan, jari dan alat yang berbentuk seperti jari, serta deteksi gerakan[13]

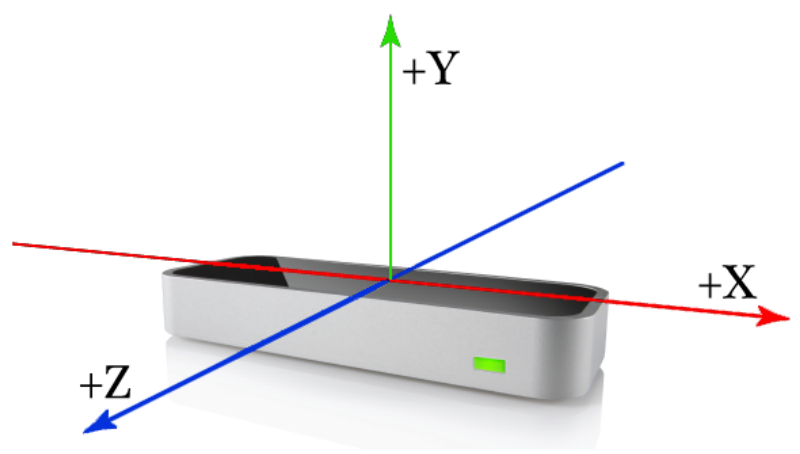

Figure 1.Sistem koordinat leap motion.

Model tangan memberikan informasi tentang identitas, posisi, dan karakteristik lain dari tangan yang terdeteksi, lengan merupakan tempat dimana tangan terpasang, dan daftar jari yang terkait dengan tangan. Gerakan jari yang terselip terhadap tangan atau terlindung dari sensor LMC biasanya tidak dapat terdeteksi. $L M C$ dapat mendeteksi lebih dari dua tangan ketika ada tangan orang lain yang muncul, namun frame hanya dapat mendeteksi dua tangan yaitu tangan kanan dan tangan kiri. Untuk hasil pelacakan yang optimal harus menggunakan maksimal dua tangan[13]. 


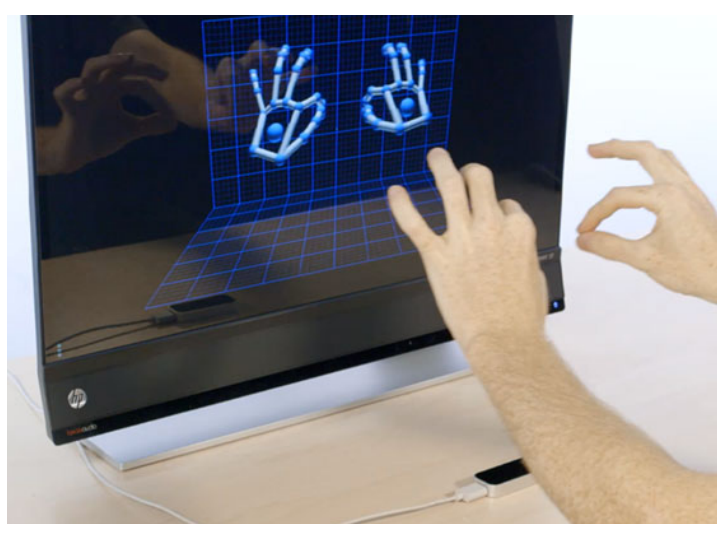

Figure 2.Deteksi tangan oleh leap motion controller.

\subsection{Logarithmic Learning for Generalized Classifier Neural Network (L-GCNN)}

L-GCNN merupakan metode klasifikasi yang digunakan pada penelitian ini. Tidak seperti jaringan syaraf tiruan berbasis radial basis function lainnya, L-GCNN menggunakan fungsi logarithmic sehingga dapat mengurangi jumlah iterasi untuk mencapai error minimal. Metode ini memiliki 5 layer utama yaitu input, pattern, summation, normalization dan output layer[14].

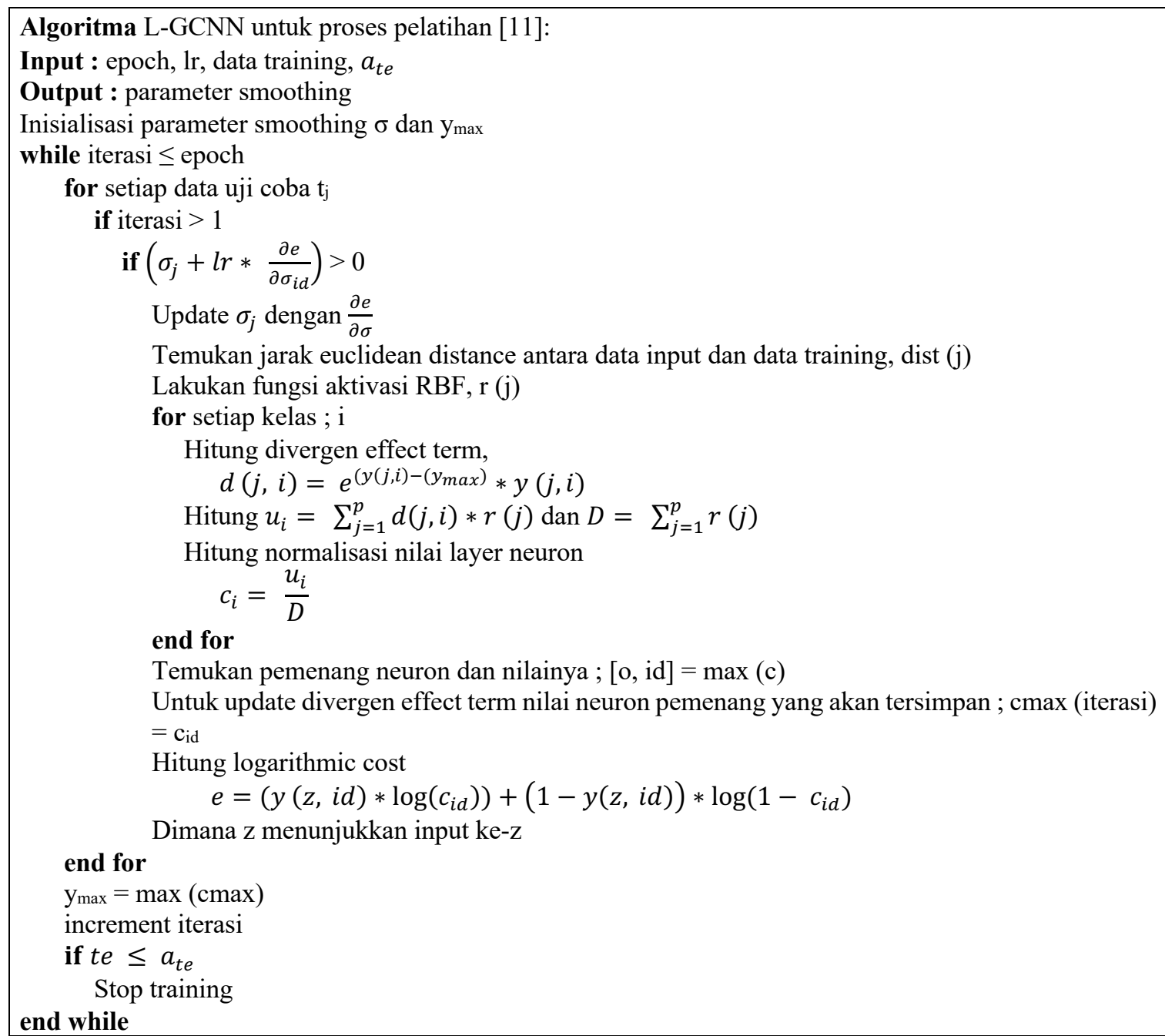

L-GCNN memiliki dua proses yaitu proses pelatihan dan proses uji coba. Pada proses pelatihan inputnya adalah epoch, learning rate, data training, dan error minimum, sedangkan outputnya adalah nilai 
parameter smoothing. Pada proses uji coba input-nya adalah parameter smoothing yang didapatkan dari proses pelatihan dan data uji coba, sedangkan output dari proses uji coba adalah kelas.

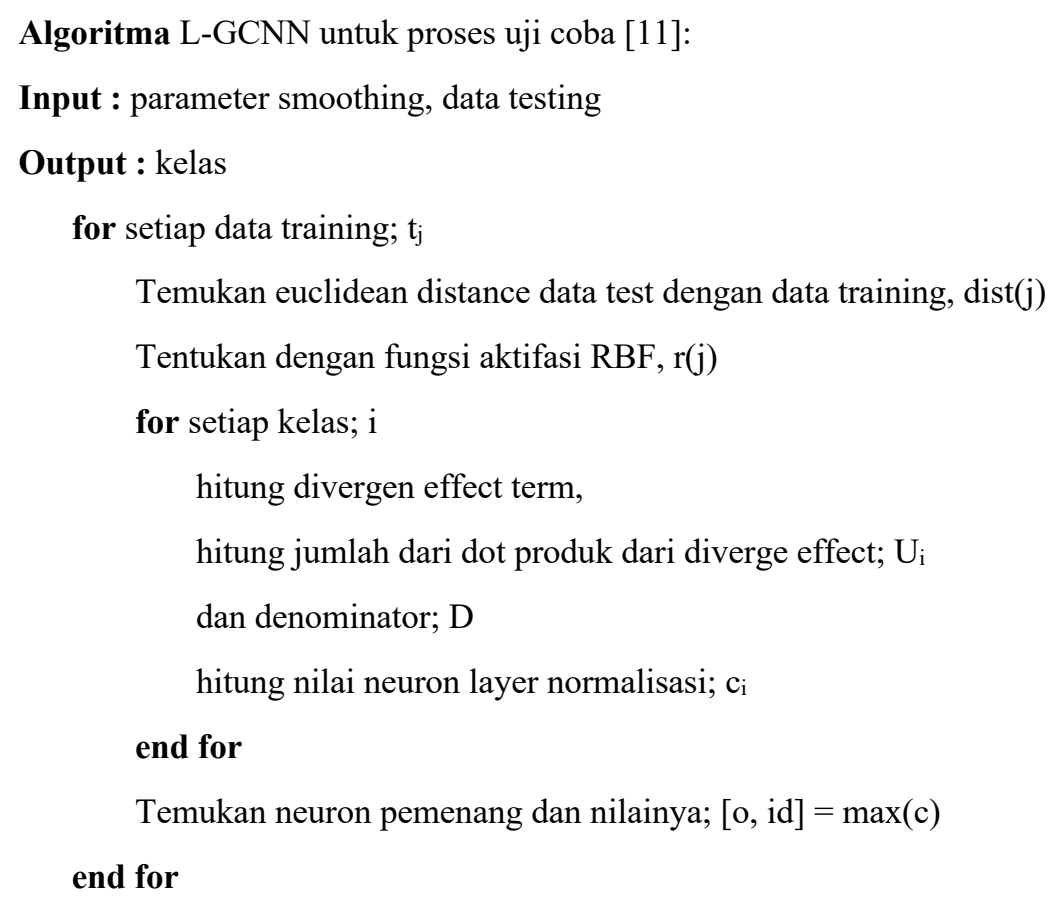

\subsection{Desain Dual Sensor LMC}

Tata letak yang pertama adalah tata letak 90 derajat dapat dilihat (Figure 3.a). Dimana kedua buah sensor $L M C$ saling membentuk sudut 90 derajat, $L M C l$ diletakkan di bidang datar atau secara horizontal sedangkan $L M C 2$ diletakkan menggunakan penyangga yang disusun secara vertikal dan dengan jarak daerah perekaman masing-masing sekitar $25-35 \mathrm{~cm}$.

Tata letak yang kedua adalah tata letak yang disebut tata letak 120 derajat, lihat pada (Figure 3.b). Kedua buah sensor hampir sama diletakkan pada desain yang pertama. $L M C l$ berada horizontal pada bidang datar, sedangkan $L M C 2$ diletakkan secara diagonal sehingga membentuk sudut sekitar120 derajat, tentunya dengan jarak perekaman yang sama dengan sebelumnya.

Tata letak yang ketiga adalah tata letak 180 derajat, lihat pada (Figure 3.c). Tata letak ini berbeda dari kedua desain sebelumnya. Kedua $L M C$ diletakkan saling tegak lurus dan horizontal. Akan tetapi sudut pandang dari capture masing-masing $L M C$ berbeda.
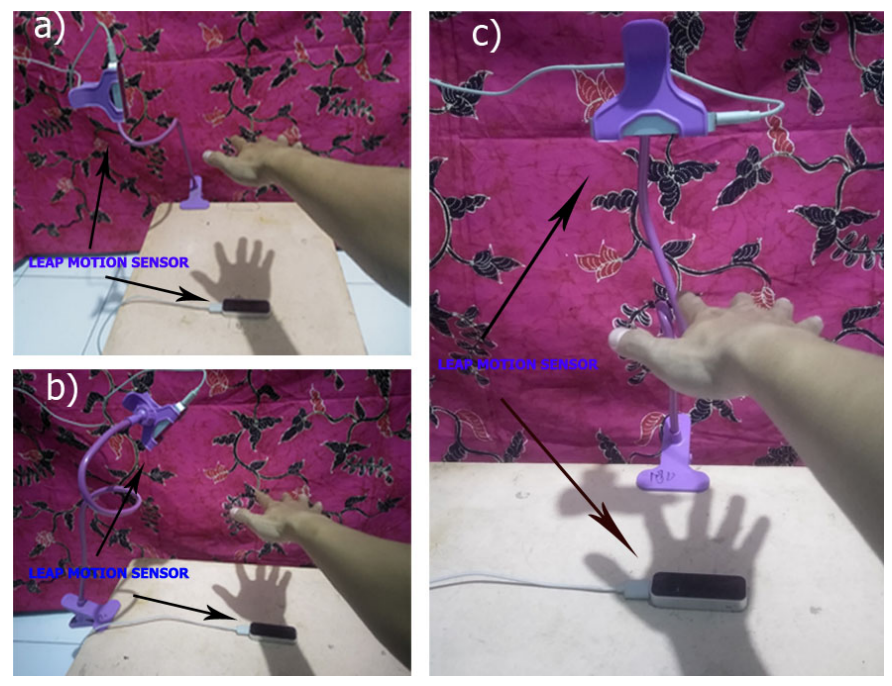

Figure 3. Desain tata letak dual sensor $L M C$. a) 90 derajat b) 120 derajat c) 180 derajat 


\subsection{Metodologi Penelitian}

Gambar di bawah adalah diagram tahapan metodologi penelitian yang dilakukan dengan menggunakan dua buah sensro LMC. Gambar di bawah juga menunjukkan proses kombinasi terjadi pada level fitur setelah proses ekstraksi fitur oleh kedua sensor $L M C$.

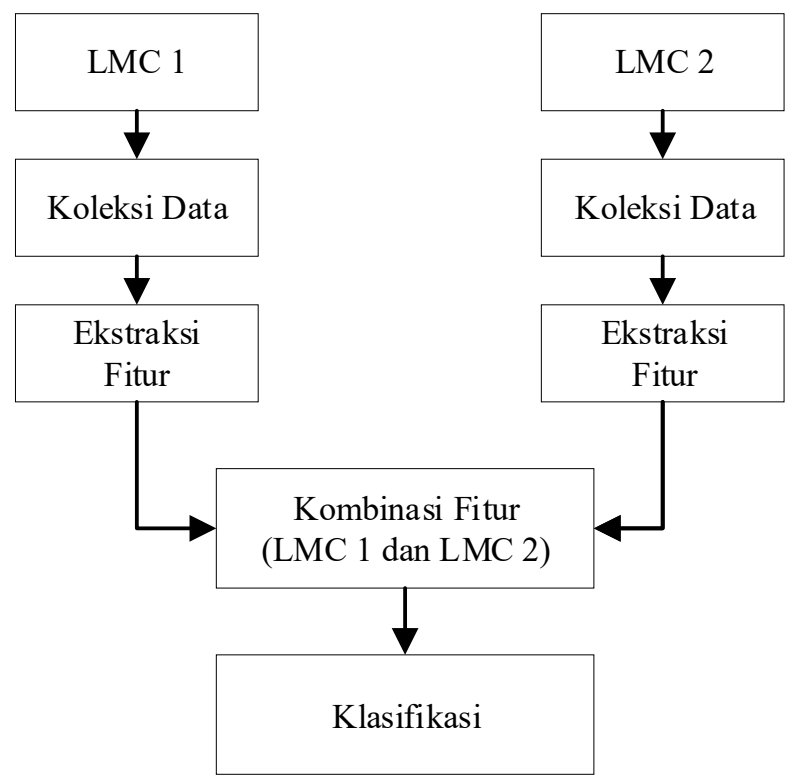

Figure 4. Sistem pengenalan isyarat Bahasa Indonesia dengan dual sensor $L M C$.

Penelitian dimulai dengan menyiapkan sensor $L M C$ sebanyak dua buah. Masing-masing sensor $L M C$ akan diletakkan pada sudut dan jarak yang telah ditentukan sesuai skenario (Figure 3). Secara singkat, sistem pengenalan isyarat bahasa Indonesia ini melalui tahapan proses yang sama antara sensor $L M C 1$ dan $L M C 2$. Proses yang dilakukan adalah pengumpulan sampel atau dataset yang diperoleh dari hasil pendeteksian pada masing-masing sensor $L M C$ terhadap isyarat tangan berdasarkan Sistem Isyarat Bahasa Indonesia (SIBI). Data koordinat isyarat tangan tersebut yang dijadikan sebagai bahan input ke dalam sistem yang akan diproses pada tahap selanjutnya. Ekstraksi fitur adalah proses penyeleksian ataupun pengambilan suatu ciri dan karakteristik dari bentuk isyarat yang telah di-input sebelumnya. Kemudian proses kombinasi dengan menggabungkan hasil ekstraksi fitur dari dua sensor $L M C$, kemudian melakukan proses pelatihan dan uji coba klasifikasi terhadap data yang telah dikumpulkan.

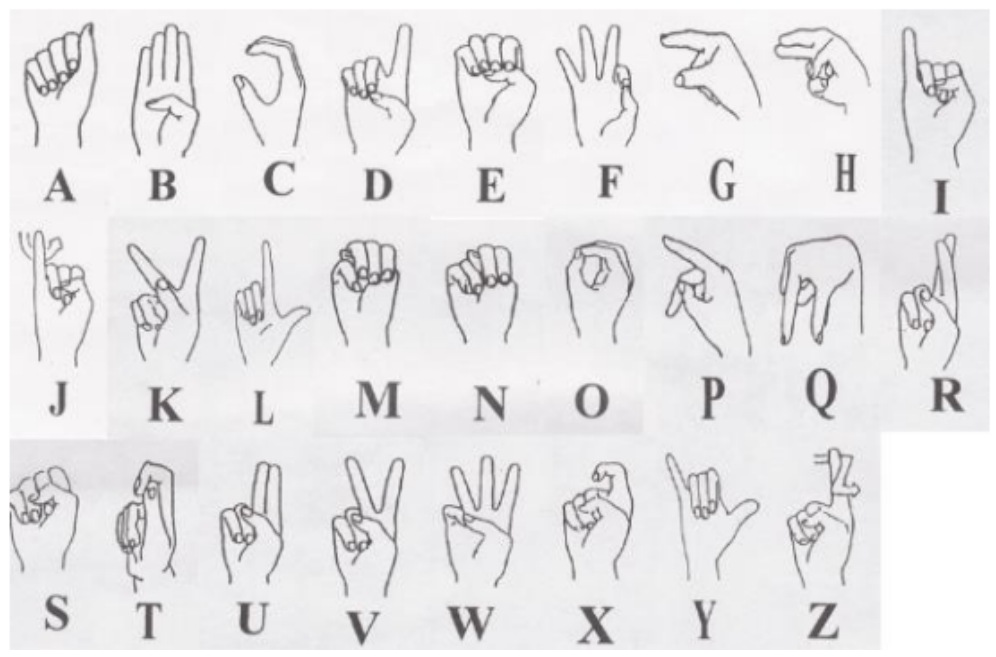

Figure 5. Sistem Isyarat Bahasa Indonesia (SIBI)

Sebanyak 26 huruf alfabet dari SIBI yang ditunjukkan pada Figure 5, akan diuji pada penelitian ini, ditambah dengan satu posisi tangan normal. Isyarat yang ada pada SIBI, dikategorikan menjadi dua bagian, 
yaitu isyarat statis dan isyarat dinamis[15]. Isyarat dinamis merupakan isyarat yang diberikan dengan gerakan jari atau tangan. Oleh karena itu, diperlukan beberapa fitur yang telah dipilih untuk memberikan ciri dari masing-masing kelas atau huruf tersebut. Untuk satu perekaman data dilakukan dengan menggunakan 10 frame, dan masing-masing huruf akan direkam sebanyak sepuluh kali. Sehingga total dari data yang diperoleh adalah 270 dataset per skenario.

Table. 1 Fitur Isyarat Statis dan Dinamis

\begin{tabular}{cccc}
\hline No & Nama Fitur & Satuan & Tipe \\
\hline 1 & Average spread & $\mathrm{mm}$ & Fitur Statis \\
2 & Average tri-spread & $\mathrm{mm}$ & Fitur statis \\
3 & Extended distance & $\mathrm{mm}$ & Fitur statis \\
4 & Hand gesture & {$[0-9]$} & Fitur Dinamis \\
\hline
\end{tabular}

Table. 2 Perekaman fitur sensor $L M C$

\begin{tabular}{|c|c|c|c|c|c|c|c|c|c|c|c|c|c|}
\hline \multirow{3}{*}{ Data } & \multicolumn{3}{|c|}{ Fitur statis } & \multirow{2}{*}{\multicolumn{9}{|c|}{$\begin{array}{l}\text { Fitur dinamis } \\
\text { Hand Gesture } \\
\end{array}$}} & \multirow{3}{*}{ Kelas } \\
\hline & \multirow{2}{*}{$\begin{array}{c}\text { Average } \\
\text { spread }\end{array}$} & \multirow{2}{*}{$\begin{array}{c}\text { Average } \\
\text { tri-spread }\end{array}$} & \multirow{2}{*}{$\begin{array}{c}\text { Extended } \\
\text { distance }\end{array}$} & & & & & & & & & & \\
\hline & & & & 1 & 2 & 3 & 4 & 5 & 6 & 7 & 8 & 9 & \\
\hline 1 & 24.04 & 740.86 & 55.8 & 0 & 0 & 0 & 0 & 0 & 0 & 0 & 0 & 0 & $\mathbf{A}$ \\
\hline 2 & 23.34 & 747.05 & 56.23 & 0 & 0 & 0 & 0 & 0 & 0 & 0 & 0 & 0 & $\mathbf{A}$ \\
\hline 3 & 37.25 & 1328.68 & 217.35 & 0 & 0 & 0 & 3 & 3 & 4 & 4 & 4 & 0 & $\mathbf{J}$ \\
\hline 4 & 34.75 & 1111.25 & 218.15 & 0 & 0 & 0 & 3 & 3 & 3 & 4 & 4 & 0 & $\mathbf{J}$ \\
\hline
\end{tabular}

\section{Analisis Hasil dan Pembahasan}

Pada penelitian ini, proes pengumpulan data sampel, pelatihan serta pengujian data dilakukan dengan menggunakan beberapa dukungan perangkat keras maupun perangkat lunak, sebagai berikut :

Table. 3 Perangkat Uji Coba Penelitian

\begin{tabular}{cccc}
\hline No & Perangkat Uji Coba & Jumlah & Keterangan \\
\hline 1 & Sensor LMC & 2 unit & Hardware \\
2 & Komputer Jinjing/ Laptop & 2 unit & Hardware \\
3 & Kabel Jaringan/ UTP & 1 unit & Hardware \\
4 & Holder Sensor & 1 unit & Hardware \\
5 & SDK LeapJava Developmentkit & - & Software \\
6 & Eclipse Java & - & Software \\
\hline
\end{tabular}

Leap motion visualizer adalah API dari developer yang men-visualisasikan bentuk tangan dalam animasi 3D yang dapat digunakan sebagai acuan dalam perekaman titik-titik koordinat tangan. Ketika visualisasi tangan dalam animasi sama bentuknya dengan tangan yang dideteksi maka titik-titik koordinat tangan yang direkam benar, karena titik-titik koordinat tangan yang direkam berdasarkan pada visualisasi tangan pada Leap Motion Visualizer.

Uji coba yang dilakukan pada penelitian ini, secara garis besar dibagi menjadi tiga tahapan. Skenario kombinasi pada level fitur yang diperoleh dari $L M C 1$ dan $L M C 2$. Pertama, skenario uji coba kombinasi pada level fitur dengan mengacu pada tata letak dua sensor $L M C$ membentuk 90 derajat (Figure 3a). Kedua adalah kombinasi pada level fitur dengan mengacu pada tata letak dua sensor $L M C$ membentuk 120 derajat(Figure 3b). Yang ketiga adalah kombinasi pada level fitur dengan mengacu pada tata letak dua sensor $L M C$ membentuk 180 derajat atau saling berhadapan (Figure 3c).

\subsection{Uji Coba Single Sensor}

Sebelum melakukan uji coba terhadap penggunaan dual sensor ini, skenario pertama adalah menguji sebuah sensor $L M C$ berdasarkan tata letak yang ditentukan. Hasil yang diperoleh nantinya akan dibandingkan dengan skenario berikutnya yaitu skenario kombinasi dual sensor. Pada uji coba ini, dataset dibagi menjadi data latih sebanyak $70 \%$ dari dataset dan $30 \%$ dataset sebagai data uji. Sehingga data uji coba menjadi 81 data dan masing-masing kelas memiliki 3 data uji. Berikut adalah hasil uji coba sensor LMC(single sensor) menggunakan LG-CNN.

Table. 4 Hasil akurasi single sensor $L M C$

\begin{tabular}{cccc}
\hline No & Letak sensor $\boldsymbol{L} \boldsymbol{M C}$ & Akurasi(\%) & Laju eror(\%) \\
\hline 1 & Horizontal/ 0 degree & 77.777 & 22.223 \\
2 & Vertikal/ 90 degree & 80.246 & 19.754 \\
3 & Diagonal/120 degree & 81.481 & 18.519 \\
4 & Horizontal/ 180 degree & 76.543 & 23.457 \\
\hline
\end{tabular}

\subsection{Uji Coba Dual Sensor}


Diagram blok yang terdapat pada Figure 4, dijjelaskan bahwa proses kombinasi fitur yang diperoleh dari $L M C 1$ dan $L M C 2$ terjadi setelah adanya proses ekstraksi fitur pada masing-masing sensor $L M C$ sebelum dilakukan tahapan penggabungan data dan kombinasi fitur. Contoh hasil kombinasi pada level fitur dari kedua sensor dapat dilihat pada Table. 5. Skenario pengujian akan diuji cobakan berdasarkan skenario dengan membagi dataset menjadi $70 \%$ data latih dan 30\% data uji, sehingga data yang akan diuji untuk masing-masing kelas sebanyak tiga data uji.

Table. 5 Kombinasi Fitur dual sensor $L M C$

\begin{tabular}{|c|c|c|c|c|c|c|c|c|c|c|c|c|c|c|c|c|c|c|c|c|c|c|c|c|}
\hline \multicolumn{24}{|c|}{ Kombimasi Fitur Dual L.MC } & \multirow{2}{*}{ ela } \\
\hline fl & f & B & f4 & f5 & 6 & f 7 & fB & $\theta$ & flo & fll & fl2 & $\mathrm{fl} 3$ & f14 & fl5 & f16 & fl7 & f18 & f19 & f 20 & f21 & 22 & 223 & f24 & \\
\hline 88.46 & 1456.95 & 65.24 & 0 & 0 & 0 & 0 & 0 & 0 & 0 & 0 & 0 & 83.86 & 1309.40 & 56.44 & 0 & 0 & 0 & 0 & 0 & 0 & 0 & 0 & 0 & A \\
\hline 88.98 & 1494.35 & 65.52 & 0 & 0 & 0 & 0 & 0 & ( & 0 & 0 & 0 & 83.86 & 1312.63 & 56.93 & 0 & 0 & 0 & 0 & 0 & 0 & 0 & 0 & 0 & A \\
\hline 172.227 & 5546.136 & 102.6 & 0 & 0 & 0 & ( & 0 & & 0 & 0 & 0 & 151.783 & 3176.999 & 101.85 & 0 & 0 & 0 & 0 & 0 & 0 & 0 & 0 & 0 & B \\
\hline 172.338 & 5539.925 & 102.73 & 0 & 0 & 0 & 0 & 0 & 0 & 0 & 0 & 0 & 153.021 & 3297.487 & 101.97 & 0 & 0 & 0 & 0 & 0 & 0 & 0 & 0 & 0 & B \\
\hline 255.609 & 7000.999 & 90.2854 & 0 & 0 & 0 & 0 & 0 & & 0 & 0 & 0 & 274.43 & 6159.798 & 83.385 & 0 & 0 & 0 & 0 & 0 & 0 & 0 & 0 & 0 & $\mathrm{Y}$ \\
\hline 254.297 & 6964.147 & 90.3276 & 0 & 0 & 0 & 0 & 0 & & 0 & 0 & 0 & 274.506 & 6162.386 & 83.129 & 0 & 0 & 0 & 0 & 0 & 0 & 0 & 0 & 0 & $\mathrm{Y}$ \\
\hline 141.902 & 3106.127 & 105.586 & 0 & 4 & 3 & 1 & 0 & & 0 & 3 & 3 & 124.215 & 2730.92 & 91.961 & 0 & 8 & 0 & 3 & 3 & 3 & 0 & 8 & 8 & z \\
\hline 137.906 & 3025.712 & 105.916 & 8 & 0 & 2 & 0 & 3 & 4 & 3 & 3 & 8 & 125.812 & 2748.678 & 92.279 & 8 & 0 & 1 & 3 & 3 & 3 & 0 & 8 & 8 & $z$ \\
\hline
\end{tabular}

1. Skenario 1 adalah uji coba kombinasi pada level fitur dengan mengacu pada tata letak dua sensor $L M C$ membentuk 90 derajat.

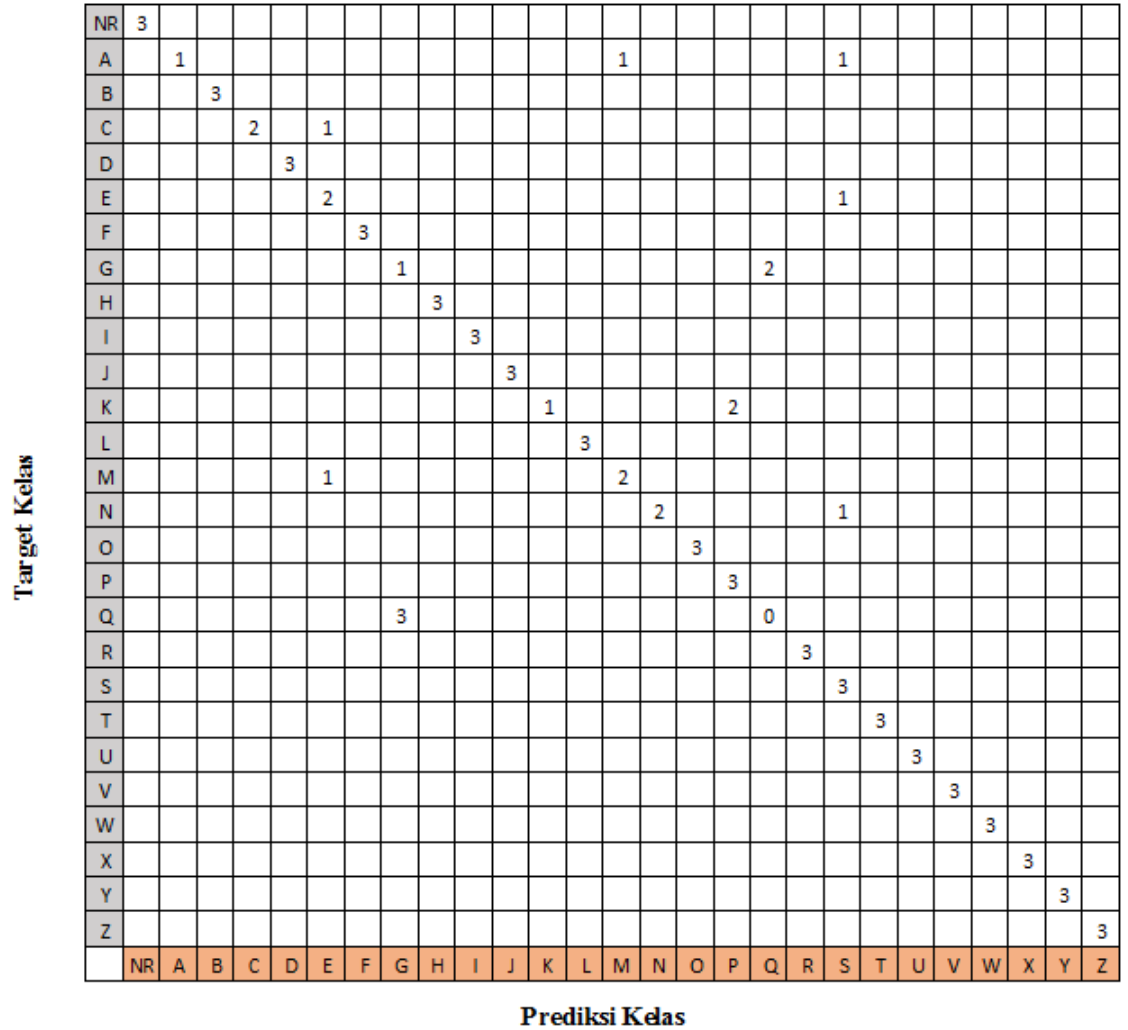

Figure 6. Hasil uji coba skenario 1.

Pada gambar di atas dapat dilihat bahwa pengenalan tiap huruf untuk setiap data uji coba mempunyai hasil yang cukup baik. Beberapa kali terjadi kesalahan pengenalan terhadap huruf A, C, E, G, M, N dan S. Kesalahan pengenalan tersebut terjadi karena fitur yang dibentuk masingmasing huruf tersebut mempunyai tingkat kemiripan yang sangat tinggi. Huruf $Q$ sama sekali tidak dapat dikenali dan terprediksi merupakan huruf G. Berbeda dengan huruf seperti huruf B, D, F, I, $\mathrm{L}, \mathrm{V}, \mathrm{W}, \mathrm{X}$, dan Y pengenalan terhadapat huruf tersebut sangat baik karena memiliki fitur yang tingkat kemiripannya rendah dibandingkan dengan huruf-huruf yang lain. Huruf $\mathrm{J}$ dan $\mathrm{Z}$ yang bersifat dinamis dapat dikenal dengan baik karena kedua huruf tersebut bersifat dinamis. Sehingga dari hasil uji coba skenario 1 dapat menghasilkan tingkat akurasi sebesar 83,95\%. 
2. Skenario 2 adalah kombinasi pada level fitur dengan mengacu pada tata letak dua sensor $L M C$ membentuk 120 derajat.

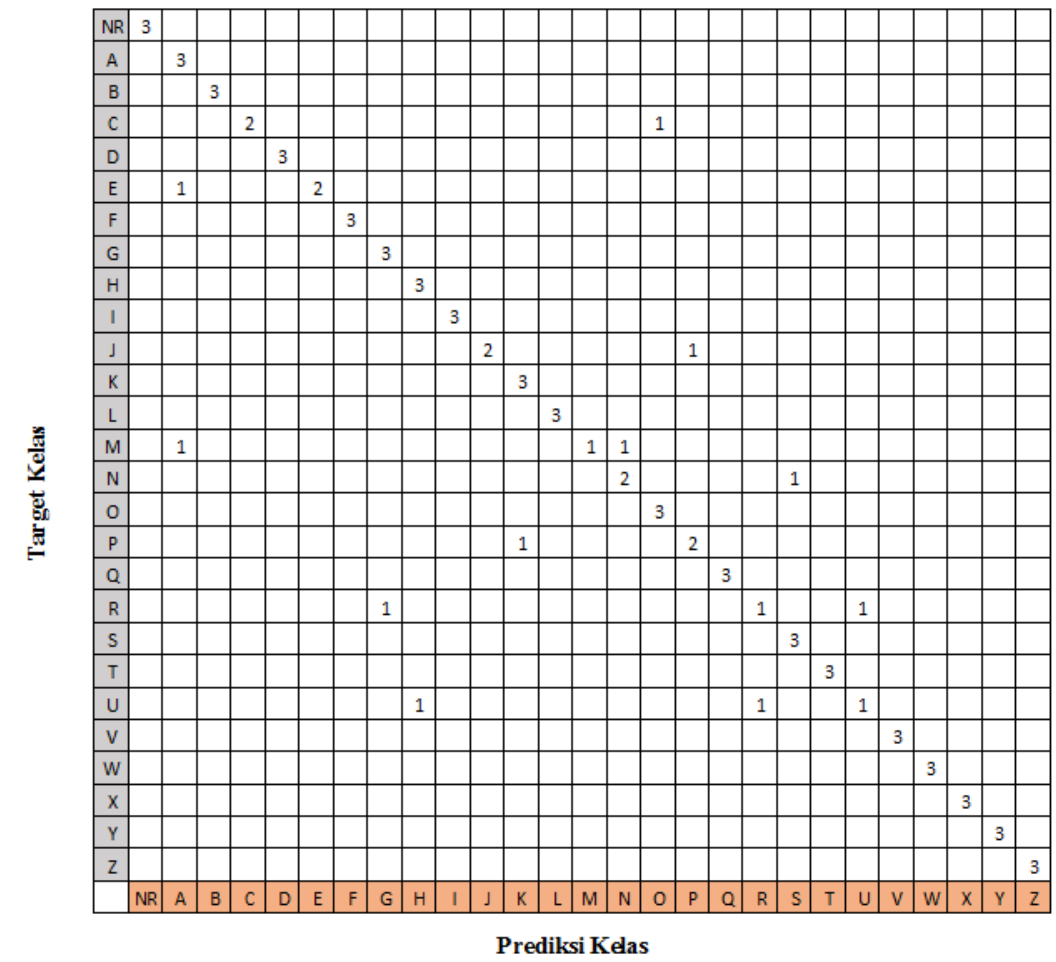

Figure 7. Hasil uji coba skenario 2.

Pada gambar di atas dapat dilihat bahwa hasil yang diperoleh dari pengujian skenario ini cukup baik dan berbeda dari hasil sebelumnya. Untuk beberapa perbandingan, misalnya huruf A, G, H dan S pada skenario sebelumnya memiliki beberapa kesalahan pengenalan. Akan tetapi uji coba skenario 2 ini, semuanya dapat terprediksi dengan baik. Walaupun masih terjadi beberapa kesalahan pengenalan terhadap huruf $\mathrm{E}, \mathrm{M}, \mathrm{N}, \mathrm{P}, \mathrm{R}$ dan $\mathrm{U}$ yang terjadi karena memiliki bentuk fitur yang tingkat kemiripannya sangat tinggi. Huruf $J$ dan $Z$ yang bersifat dinamis dapat dikenal dengan baik dan hasil akurasi pada skenario ini mencapai $86,42 \%$.

3. Skenario 3 adalah kombinasi pada level fitur dengan mengacu pada tata letak dua sensor $L M C$ membentuk 180 derajat atau saling berhadapan. 


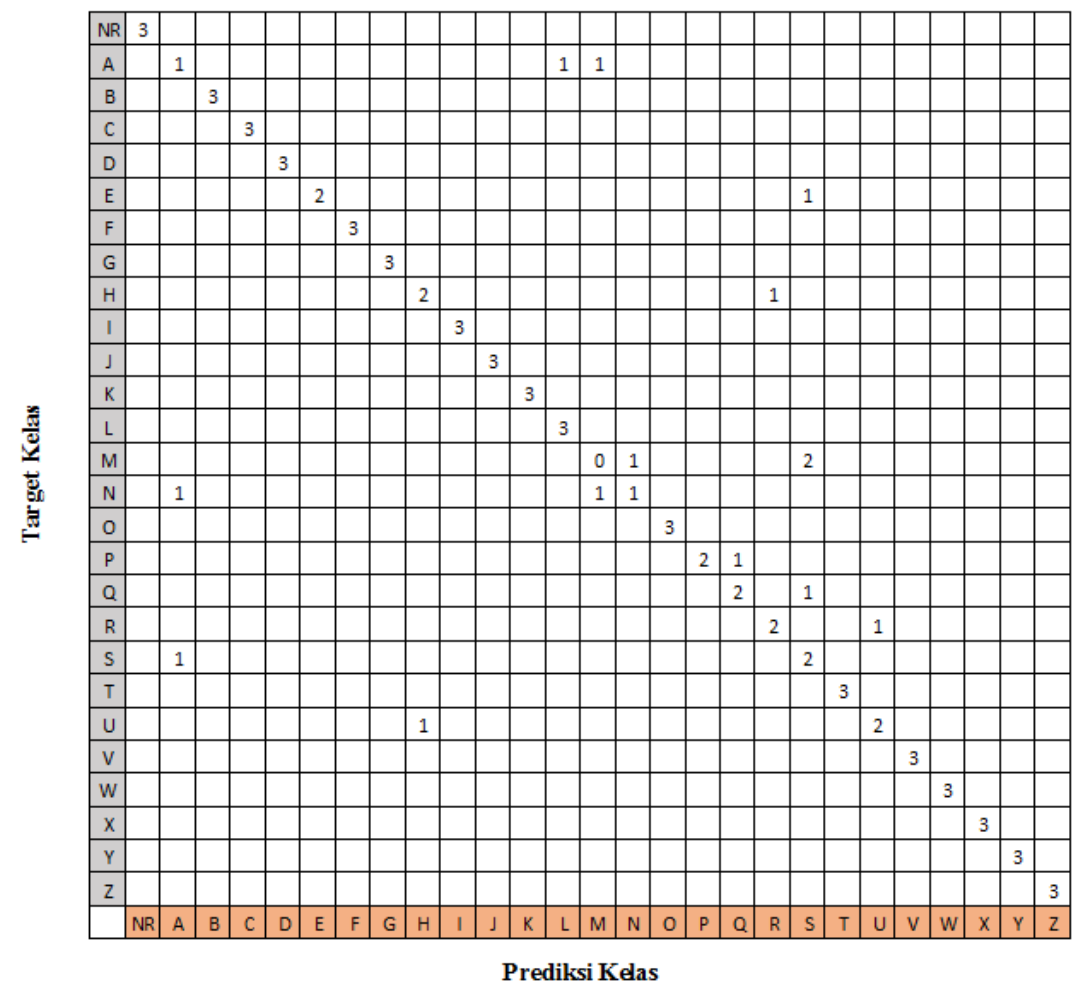

Figure 8. Hasil uji coba skenario 3.

Gambar di atas menunjukkan hasil pengenalan yang dilakukan terhadap data uji coba. Hasil yang diperoleh untuk masing-masing kelas sangat variatif dibandingkan dengan skenario sebelumnya. Kesalahan pengenalan masih terjadi terhadap huruf-huruf dengan tingkat kemiripan fitur yang tinggi seperti A, H, M, N, P, R, S dan U. Terlebih huruf M sama sekali tidak dapat dikenali, karena bentuknya yang sangat mirip dengan huruf $\mathrm{N}$ dan $\mathrm{S}$. Huruf $\mathrm{J}$ dan $\mathrm{Z}$ yang bersifat dinamis dapat dikenal dengan baik, sehingga dari keseluruhan uji coba pada skenario 3 ini dapat menghasilkan akurasi pengenalan mencapai $82,71 \%$ dan berikut adalahgrafik perbandingan uji coba yang dilakukan.

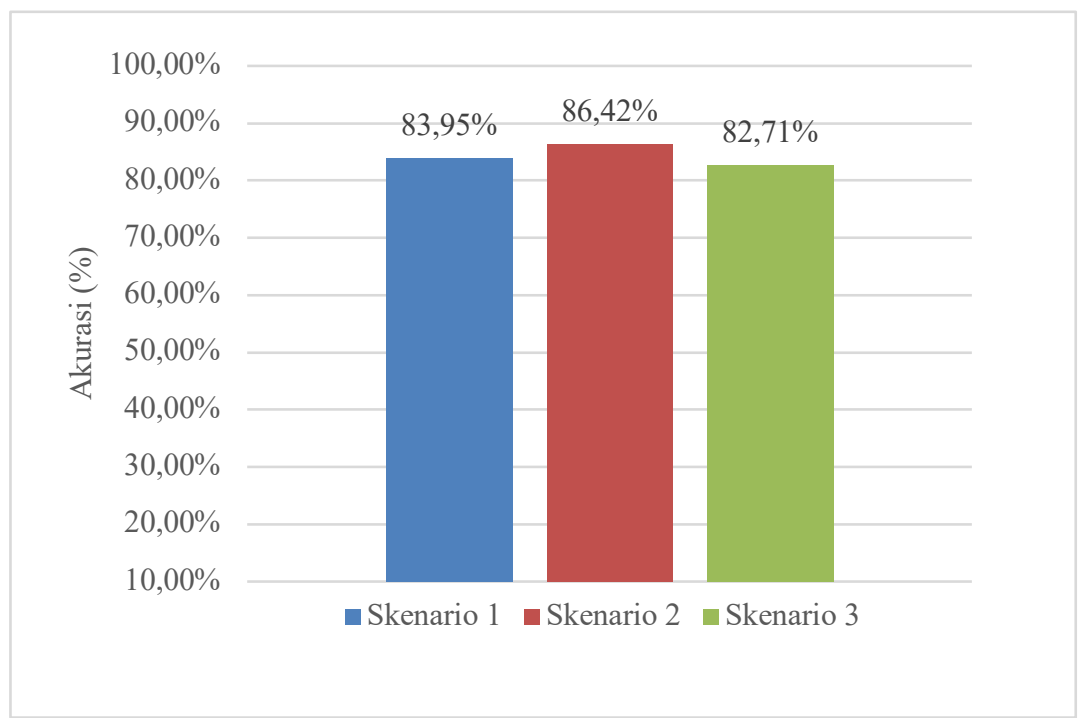

Figure 8. Perbandingan hasil akurasi skenario uji coba. 


\subsection{Pembahasan}

Dari hasil uji coba yang dilakukan, kombinasi dari penggabungan data fitur yang diperoleh dari masing-masing sensor mempunyai akurasi pengenalan yang baik dibandingkan penggunaan single sensor $L M C$. Pada penelitian sebelumnya, hasil yang diperoleh pada penggunaan single sensor dapat dijelaskan bahwa peningkatan akurasi diperoleh dari penggabungan data fitur statis dan fitur dinamis yaitu akurasi 76,30\% meningkat menjadi 82,97\% atau peningkatan akurasi sebesar 6,67\%[11]. Walaupun dalam pengujian penelitian ini masih terjadi beberapa kesalahan, keselahan pengenalan pada tiap-tiap skenario disebabkan oleh hurufhuruf yang memiliki kemiripan bentuk fitur. Namun secara keseluruhan, dapat dikatakan pengenalan bahasa isyarat yang dilakukan sangat baik dan mampu menghasilkan nilai akurasi yang cukup tinggi. Jari yang tertutup atau yang terhalang oleh jari lainnya dapat diminimalisir dengan adanya letak sensor lainnya. Fitur dinamis yaitu fitur yang diperoleh dari gerakan tangan juga dapat dikenali dengan baik pada skenario pengujian 1 sampai skenario 3. Dengan mengacu pada tata letak dan sudut kedua sensor, akurasi yang dihasilkan dapat meningkat dibandingkan dengan penggunaan satu sensor $L M C$. Skenario dengan hasil akurasi tertinggi diperoleh dari hasil skenario skenario 2. Skenario 2 memiliki akurasi sebesar 86,42\%, dimana skenario penggabungan fitur dari dua sensor $L M C$ tersebut mengacu pada sudut dan tata letak sensor 120 derajat. Berdasarkan analisis yang dilakukan, hal ini dapat terjadi karena daya capture sensor yang maksimal terhadap isyarat tangan yang diberikan dengan bersumber dari dua buah sensor $L M C$. Huruf-huruf yang memiliki tingkat kemiripan yang tinggi dapat diminimalisir tentunya dengan mengacu pada letak kedua sensor $L M C$. Sehingga pembentukan isyarat yang cukup sulit dapat diatasi dengan baik. Oleh karena itu kelemahan $L M C$ yang tidak dapat mengenal isyarat bahasa Indonesia seperti jari yang tersembunyi, terlipat atau terhalang oleh jari lainnya, dapat dideteksi dengan skenario yang mengacu pada tata letak kedua sensor dan juga kombinasi data fitur yang dilakukan pada penelitian ini.

\section{Conclusion}

Penambahan dan seleksi fitur pada penelitian ini sangat diperlukan untuk dapat menambah keragaman ciri dan karakteristik setiap huruf, karena sistem isyarat bahasa Indonesia atau SIBI memiliki beberapa isyarat yang memiliki kemiripan yang tinggi. Setelah berbagai uji coba yang dilakukan dan hasil yang diperoleh maka dapat ditarik kesimpulan bahwa adanya kombinasi yang dilakukan pada level fitur dari dua sensor $L M C$, baik fitur statis dan dinamis pada sistem isyarat bahasa Indonesia dapat dikenal dengan baik dengan rata-rata akurasi 84,36\%. Dan dengan mengacu pada tata letak dan sudut sensor $L M C$ serta kombinasi fitur yang diperoleh dari dua buah sensor $L M C$, hasil yang diperoleh dapat mengalami peningkatan hasil akurasi mencapai 5,35\%. Skenario terbaik dalam penggunaan dual sensor ini adalah penggunaan dual sensor yang letaknya mengacu pada skenario 2 yaitu sensor saling berhadapan dengan membentuk sudut 120 derajat dengan hasil akurasi mencapai $86,42 \%$.

\section{References}

[1] S. Kausar and M. Y. Javed, "A Survey on Sign Language Recognition," 2011 Front. Inf. Technol., no. October, pp. 95-98, 2011.

[2] C. Oz and M. C. Leu, "Linguistic properties based on American Sign Language isolated word recognition with artificial neural networks using a sensory glove and motion tracker," Neurocomputing, vol. 70, no. 7, pp. 28912901, 2007.

[3] M. M. Zaki and S. I. Shaheen, "Sign language recognition using a combination of new vision based features," Pattern Recognit. Lett., vol. 32, no. 4, pp. 572-577, 2011

[4] P. Das, R. De, S. Paul, M. Chowdhury, and B. Neogi, "ANALYTICAL STUDY AND OVERVIEW ON GLOVE BASED INDIAN SIGN LANGUAGE INTERPRETATION,” pp. 313-318, 2015.

[5] a. S. Elons, M. Abull-Ela, and M. F. Tolba, "A proposed PCNN features quality optimization technique for pose-invariant 3D Arabic sign language recognition,” Appl. Soft Comput. J., vol. 13, no. 4, pp. 1646-1660, 2013.

[6] M. Mohandes, S. Aliyu, and M. Deriche, "Arabic sign language recognition using the leap motion controller," 2014 IEEE 23rd Int. Symp. Ind. Electron., pp. 960-965, 2014.

[7] N. Praveen, N. Karanth, and M. S. Megha, "Sign language interpreter using a smart glove," 2014 Int. Conf. Adv. Electron. Comput. Commun. ICAECC 2014, 2014.

[8] A. Kuznetsova, L. Leal-Taixe, and B. Rosenhahn, "Real-Time Sign Language Recognition Using a Consumer Depth Camera," 2013 IEEE Int. Conf. Comput. Vis. Work., pp. 83-90, 2013.

[9] L. Geng, X. Ma, B. Xue, H. Wu, J. Gu, and Y. Li, "Combining features for Chinese sign language recognition with Kinect," IEEE Int. Conf. Control Autom. ICCA, no. 61240052, pp. 1393-1398, 2014.

[10] C.-H. Chuan, E. Regina, and C. Guardino, "American Sign Language Recognition Using Leap Motion Sensor," 2014 13th Int. Conf. Mach. Learn. Appl., pp. 541-544, 2014.

[11] Supria, D. Herumurti, and K. Wijayanti Nurul, "Pengenalan sistem isyarat bahasa indonesia menggunakan kombinasi fitur statis dan fitur dinamis LMC berbasis L-GCNN," JUTI - J. Teknol. Infomasi, vol. 14, no. 2, pp. 
217-230, 2016.

[12] G. Marin, F. Dominio, and P. Zanuttigh, "Hand gesture recognition with leap motion and kinect devices," 2014 IEEE Int. Conf. Image Process. ICIP 2014, pp. 1565-1569, 2014.

[13] I. Leap Motion, "LEAP motion," 2015.

[14] B. M. Ozyildirim and M. Avci, "One pass learning for generalized classifier neural network," Neural Networks, vol. 73, pp. 70-76, 2016.

[15] W. N. Khotimah, R. A. Saputra, N. Suciati, and R. R. Hariadi, "Comparison between Back Propagation Neural Network and Genetic Algorithm Back Propagation Neural Network for Sign Language Recognition,” vol. 00, pp. 0-5, 2015. 